\title{
The use of KAAPS in newspapers
}

\author{
Anastasia de Vries \\ University of the Western Cape
}

Correspondence to: adevries@uwc.ac.za

\begin{abstract}
In the increasingly competitive media landscape newspapers, among others, are under pressure from digital and social media. As a result, the performance and positioning of traditional Afrikaans newspapers like Rapport, Beeld, Die Burger and Volksblad, as well as the forms of Afrikaans they use, are constantly scrutinised in surveys about the relevance and profitability of the Afrikaans print media. These surveys often point to the use of Afrikaans 'as spoken by the people' in emerging newspapers like Son and Son op Sondag, as the main reason for the growing popularity, healthy sales figures and advertising revenue of these two newspapers. As a result, Son developed into the largest Afrikaans daily in an Afrikaans print market long dominated by established titles like Beeld, Die Burger and Volksblad. In view of this, this contribution will firstly investigate the profitability (in monetary terms and circulation) of actually using Kaaps in newspapers. Secondly, it will focus attention on the use of this form of Afrikaans in traditional newspapers in which Standard Afrikaans is the dominant form. The question is: What is the nature of the Kaaps in these newspapers compared to the Kaaps in Son specifically? The aim of this contribution is to explore how Afrikaans newspapers create space for the use of colloquial varieties in general and Kaaps specifically, and to determine the relevance or function of Kaaps in the news domain. On the one hand the focus will be on columns in which Kaaps is the medium and on the other, on newspaper articles about the Afrikaans language variety. The data on which this paper is based were firstly, the responses to a list of questions posed to the news-editor of Son, and secondly a critical content analysis and interpretation of the manifestations of Kaaps in this newspaper in comparison to the forms in the more established Afrikaans newspapers. The general perceptions of, and attitudes towards, the use of colloquial varieties of Afrikaans, collated in a 2012 survey among readers, are also taken into account.
\end{abstract}

\section{INTRODUCTION: BACKGROUND}

The constant pressure on newspapers from new or digital media in a highly competitive media landscape, which has been marked by a drop in circulation numbers for traditional Afrikaans newspapers (Rapport, Beeld, Die Burger en Volksblad), is often perceived as the encroaching, inevitable demise of the print media. In contrast to this, publications in the emerging markets - Son, Son op Sondag, Kuier - seem 
to flourish. Their use of colloquial language, among others Kaaps, is often cited as one of the reasons for their growth. In view of this, this contribution investigates the profitability resulting from this language usage, particularly Kaaps, in both established and emerging Afrikaans newspapers. It also considers the possible functions and nature of Kaaps in these papers, and the manner in which columns act as a vehicle to create space for Kaaps in these domains.

For this purpose the following material, in addition to a content analysis of the selected columns, applies: (i) the responses in 2012 of Neil Scott, news-editor for Son, to a questionnaire regarding these issues ${ }^{1}$, (ii) the report Media24 Afrikaans Newspaper Market Analysis: A qualitative probe into relevant reader groups (2012) which resulted from an investigation by Kuper Research into among others language preferences and (iii) the Audit Buro of Circulation (ABC) 2016 circulation data for newspapers. The searchlight also falls on the extent to which Afrikaans newspapers create space for diverse varieties, and Kaaps in particular, focusing on columns in Son, Die Burger and Rapport.

This contribution does not attend

to the sociolinguistic aspects of the
Kaaps manifested in newspapers and neither does it pass value judgments on the authenticity and/or credibility of its use and orthographic reproduction by the writers in question. These issues should rather be empirically researched in further studies. Of relevance here is a content analysis of the selected columns, concentrating on the functionality and nature of the Kaaps in Afrikaans newspapers. The results of this analysis will be discussed in the conclusion.

But first the focus is on the profitability, or not, of colloquial language forms in newspapers. It is significant that the growth of Son into 'the largest Afrikaans daily newspaper' (Scott 2012) since 2003, is usually attributed to its use of different Afrikaans varieties, and Kaaps specifically. In 2015 this newspaper had more than a million readers per day, with daily sales of 79776 in the Western Cape, about 18000 in the Eastern Cape and more than 2000 in Kimberley, Northern Cape (see ABC figures for October - December 2015). The Kuper report of 2012 (see section 9.3 ) indicates that every copy of Son sold, accounts for at least 11 readers while the traditional Afrikaans or more established newspapers have about six readers per paper.

1 The questionnaire consisted of the following questions:

a. Is the Afrikaans you use for example in Son, Kaaps? How would you define it (short sentence)?

b. How do you determine the Kaaps (or however you refer to it) you use? Who determines how it should be used: your editorial team, linguists, readers?

c. And for the rural areas - do you also use Kaaps?

d. Are your readers only coloured language users of Kaaps?

e. Do you attract enough advertising income to counter possible slumps in circulation? In short: is it economically viable to use Kaaps as a dominant variety in your newspaper(s)? Who advertises in your newspaper(s) - companies like banks, PnP, et cetera? Is your advertising revenue growing/falling or stagnant? Why?

f. What are your circulation figures (in terms of sales)? For Son? And Son op Sondag? Is it growing/falling?

g. How many readers do you have?

h. How, if at all, does the language you use play a role in people's choice for buying your newspapers?

i. Are you sometimes critised for your language usage? By whom? Why? 
In addition, according to the $\mathrm{ABC}$ data Die Burger sold 53463 newspapers per day in the Western and Eastern Cape combined, Beeld $46 \quad 627$ in predominantly Gauteng and the NorthWest, while Volksblad at 16919 was primarily operative in the Free State and parts of the Northern Cape. This data also showed that the Saturday edition of Die Burger shrank from 70666 to 66624 and Saterdag-Beeld from 46043 to 42629 . As far as the weekly Sunday papers are concerned, Son op Sondag stood at 60000 sold copies, compared to Rapport that had a circulation of 138034 in the last quarter of 2015, down from 156211 the previous year (ABC, October - December 2015).

Is it purely coincidental that the circulation figures of established papers like Die Burger and Rapport have dropped significantly since the emergence of Son and Son op Sondag? If no coincidence, is it because the latter are cheaper than the former or does the language forms in which people's stories appear, play a role in preferences for Son and Son op Sondag?

At this point it is worth noting that Son, as produced in the Western Cape and in Kaaps - failed to make inroads in the northern provinces. In fact, it was soon replaced by the now defunct SondagSon, aimed at the lower income, primarily white reader. The language use ranged from spoken Afrikaans, English and slang to crude language.

In contrast, Son op Sondag, circulated in the same areas as Son, reflects less slang, crude language and more importantly, less distinctive colloquial forms like Kaaps (Scott:2012). Because of the latter the following section will concentrate on the Afrikaans, particularly Kaaps, used in Son, to the exclusion of Son op Sondag.

\section{Kaaps in Son}

The responses of Neil Scott, news editor of Son, to the questions posed to him in 2012 (see section 9.1, footnote 1 ), indicate the challenges all newspapers have to face in a growingly digital environment, including those characterised by the use of Kaaps and/or other Afrikaans varieties, besides the standard form. However, while the more established titles with their shrinking circulation become ever more dependent on advertising revenue in order to be profitable, emerging papers like Son report a growing share in the advertising market coupled with a relatively steady circulation turn over.

According to Scott, Son's circulation dropped slightly due to a weaker economy but its income from advertisements performed better than expected for the financial year 20112012. In a follow-up to these questions in 2016, Eldridge Jason, content editor for Son, confirmed that the newspaper is exponentially drawing advertisements from major chain stores, as well as local business. Though the newspaper initially positioned itself towards historically coloured communities, surveys have shown that the paper is increasingly bought and read by other communities as well. The Afrikaans 'as spoken by the people' is one of the reasons why people are buying Son, according to Jason.

He concurs with Scott (2012) that the use of Kaaps, or not, is determined by various factors, among which the geographical regions for the two daily editions of Son i.e. 'one for the region Boland/West Coast/Southern Cape where we write more in the language of those people' and 'our metropolitan edition' in 'Kaaps, Cape Flats language'. This means that news reports and stories about events concerning speakers on the Cape Flats may contain more markers 
of Kaaps than for example stories about experiences in a Boland or rural context.

Thus, depending on the people in the news and the contexts within which their stories originate, news reports in Son may contain more Kaaps on a particular day than on others when the subjects and their stories may dictate greater prominence to an informal (Standard) Afrikaans with elements of Kaaps or other colloquial varieties.

How these varieties are transcribed to text is primarily the task of Son's reporters: "[They] determine how the language spoken by the people, should be written. They are the ones speaking directly to the people' (Scott 2012).

As such, reporters are not simply instrumental in documenting news items and/or stories connected to the life experiences of readers but act as scribes of the language used to tell these stories, i.e. the various forms of Kaaps used by subjects and readers. Does this imply that on any given day, dependent on the reporter, news items in Son may or may not reflect Kaaps or the diversity inherent to it?

In narrating the story, reporters under pressure from deadlines, will indeed opt for an informal Afrikaans, but have to stay true to form as far as the direct speech of those they give voice to are concerned (Jason 2016). In addition, tight deadlines and fewer copyeditors sometimes make it impossible to 'translate' news in Kaaps to the Afrikaans spoken in for example rural areas or stories from these regions to Kaaps (Scott 2012).

This calls into contention the findings of Joline Blignaut (2014) that the Kaaps in Son is not a 'true' reflection of this variety but should rather be considered 'an informal Afrikaans with elements of Kaaps' (see 'Opsomming' [Summary] in Blignaut 2014). The question is if Son is not in fact indicative of the heterogeneous nature of Kaaps, of variety within a variety reflecting the various communities, cultures, sub-cultures and geographical areas in which its diverse manifestations are rooted, within and alongside other Afrikaans varieties characteristic of the geographical regions and communities accessed by Son and which also find their way into this newspaper.

An exploration of the daily metropolitan and rural editions of Son undertaken by this researcher in the week of 23 to 27 May 2016 brought to light that Kaaps (and other Afrikaans varieties) are indeed alternated with the standard variety when information is presented in the third person and direct speech in news reports, articles and columns. In this regard Hendricks (2011, 2012) distinguishes between narrative code(s), the code(s)/types of Afrikaans in which reporters retell events, and the 'citing code(s)' or the codes/forms of Afrikaans in which the subjects themselves give voice to what happened. Genres such as sport reports and recipes are almost exclusively in the standard variety.

Particularly the narrative and anecdotal contributions of Eldridge Jason, Salmon Smith and Tracy-Lynn Williams to the column 'Oom Sonnie se stukke' [Uncle Sonnie's stories] reflect this interplay between Kaaps, other colloquial varieties and informal forms of Standard Afrikaans. The examples (a-d) below are extracts from their contributions to this column. The following key applies: those sections where a narrator takes the floor in the four extracts, i.e. the narrative code, is in the regular font; sections in direct speech (citing code), is bold while typical Kaaps phenomena are underlined.

These three columnists regularly turn out contributions in which the 
narrators primarily use an informal Standard Afrikaans sporadically interspersed with Kaaps markers, while the utterances of their characters in direct speech show a higher frequency of typical Kaaps phenomena (see (a), (b) and (c)). In Salmon Smith's contributions the narrator as well as the speaking characters use an informal standard variety in which markers of Kaaps are distinctly absent (see example (d)).

(a)

Die trane rol oor Melody Jones se wange. "Daddy, hoe kon jy?!" gil sy op haar pa. Geldgat Jones staan egter met 'n mond vol tande en probeer oogkontak met sy dogter vermy. "A-nee-a," sê Big Boi. Sy klein, ronde gesiggie is in een groot smile gekreukel. "Mens praat mos nie só met Daddy Dearest nie. Waar's djou respect, huh?" Pokken tree vorentoe, maar Big Boi rig onmiddellik die vuurwapen in sy rigting. "Make my day, pêl. Make my day," sê hy dreigend. Pokken draai na Geldgat Jones. "Djy bly nou maar eenmaal 'n stuk gemors. Vir once in my lewe wou ek djou trust, but djy bewys net wee' dat vullis nooit change nie." (...) Big Boi lag hardop. "Jarre, ek sou gelikes het om dié bitch fight heeldag te kyk, but selfs Days is bietere as djulle moffie-talk. Besides, ek het 'n kroon om te gaan collect. Jones, vat djou meisiekind en lines. "Ek en Pokkel Booze het grootmenssake om te discuss. (Jason, Eldridge 2012b)

(b)

Dis amper 17:00. Ant Merl is weer laat, sy moes seker maak dat Tori se meisietjie by haar ander ouma afgelaai word. Die deal is dat almal R20 bygooi om die tenk vol te maak. Ouma Doris staan en wag al by die venster van haar maisonette in Westridge. Entjie in die hand, drink sy stadig aan haar koffie. Sy is mos so excited en ever ready om haar voete by Antie Gawa se deure te sit. Ant Merl trek toe op en hoot. 'Jirre, Merl, is die nou halfvyf? 'n Halfuur later? My make-up trek al hard!" wil Ouma weet. Ouma Doris sluit toe haar voordeur toe, maar voordat sy in die klein Opeltjie klim, hardloop sy weer terug en check dat die deur reggesluit is. Geïrriteerd skreeu Merl uit die kar: "Nee, gonna, Doris, is alles hierdie nou nodig? Jy kla dat ek laat is, maar dan vat jy nog jou eie tyd." Ant Merl se man het al weer laat huis toe van sy druggie-vriende gekom. "Merl, is djy orraait?" vra Ouma bekommerd. "Nee, ek weet nie meer nie. Daai man is 'n burden, hy kyk nie meer agter sy familie nie," antwoord Ant Merl terwyl sy wegtrek. (Williams, Tracy-Lynn 2016)

(c)

Die ses tikkoppe lyk ver van hêppie toe Jeppo by hul flat inbars. Jeppo kyk die manne een vir een deur terwyl hy tydsaam sy leerhandskoene aantrek. Nie een van die ouens lyk soos Kenny Moses nie. "Hallo, wies djy!?" vra een van hulle baie kras en gluur Jeppo op en af aan. "Waar is Mistas die Ystervoël?" ignoreer Jeppo die tikkop se vraag. Sy stem klink ongestoord en hy is min gespin met die vuil kyke wat die tikkoppe hom gee. 'Hy's hier uit met 'n visstok en 'n stukkie steenkool. Hy't iets gepraat van treine vang. Hahaha!" sak 'n ander ou met so 'n groot kop laggend af. Die eerste een gluur die ou met die groot kop woedend aan. "Hallo, Koppe! Djy moetie nog kô jokes maak nie. Dié jong kom bars sommerso hier in 
(...)," sê hy. Koppe vryf selfbewus oor sy kop. "Sorry, ou Manna. Niks soe bedoel nie, my broe." Manna draai na Jeppo. "Wie's djy?" vra hy dan kortaf. "Ek's jou ma se antie," antwoord Jeppo sarkasties. Op daardie oomblik kom 'n seun van so sewe jaar by die sitkamer ingeloop. "Pappa, ek is honger," sê hy aan Manna.

(Smith, Salmon 2013)

(d)

Anthony Leyman, sy gesig grotesk in die maanlig, se vinger krul om die sneller. "Nee! Asseblief, moenie!" gil Lucien en probeer regop kom, maar die grond is té glyerig. Vaagweg hoor hy iemand sy naam noem. Die geluid kom uit die huis. Maar dis dan sy ma se stem, besef hy. Anthony gryp hom aan die skouers en begin hom te pluk. Hy kyk op en is verbaas om sy ma se gesig in plaas van Anthony se gesig te sien. Toe sit hy skielik regop en kyk verward rond. Hy is dan in sy kamer. "Is jy oukei, my kind?" vra Maria hom. Hy kyk op na haar. "Ek het 'n nagmerrie gehad, Ma," sê hy. "Ek het jou hoor gil en toe breek 'n glas. Dis dié dat ek kom kyk het wat aangaan." Sy vee die sweet van sy voorkop af. Sy kyk na die skerwe van 'n koeldrankglas in die hoek van sy kamer. Lucien kyk ook daarna. "Ek moes dit seker in die spartel van die bedkassie afgeklap het. Ek het van Anthony gedroom, Ma. Daar was woede en wraak in sy oë. Hy wou my doodmaak." Maria druk Lucien teen haar vas. "Toemaar, my kind, hy is nou veilig agter tralies." "Ma, wat is die kanse dat hy bail kan kry?" Lucien kyk vol afwagting na sy ma. (Smith, Salmon 2010)
In my opinion the first three contributions (a-c) to 'Oom Sonnie se stukke' are credible mirror images of the diversity within Kaaps. It therefore stands to reason why Hendricks (2016) could put data from this column to good use in the first chapter of Kaaps in Fokus to illustrate the linguistic markers of Kaaps.

The different manifestations of Kaaps in this column confirm that Kaaps is no homogenous variety and that it can stand its ground in a newspaper alongside other varieties of Afrikaans. It is significant that Son to its sole credit has created a whole new generation of (newspaper) readers (see the Kuper Report 2012, section 9.3; also 9.1).

Van der Rheede (2012:123) is of the opinion that Son plays an important role in the advancement of 'linguistic creativity' among reporters and readers: 'Linguistic creativity offers a basis for optimally unlocking the social, educational and economic value of the Kaaps vernacular Afrikaans.' Of this the traditional Afrikaans newspaper seemed to take due cognisance and columns in Kaaps began appearing in, among others, Die Burger and Rapport since the early 2000's, while articles about Afrikaans increasingly included Afrikaans colloquial varieties (see section 9.3).

However, it remains an open question if the space allocated to colloquial Afrikaans, including Kaaps, in the traditional, established newspapers are materially profitable. According to Kay Karriem (2013), editor of Kuier, this magazine is a success exactly because the stories of her predominantly coloured readers in the Afrikaans they speak, are the 'main attraction' and not, as is the case in the traditional publications, served as a 'side-dish'. Significantly under her leadership Kuier more 
than doubled its circulation in this increasingly competitive news market. Her retort about main attraction vs. side-dish followed on an interview with Waldimar Pelser in 2013, shortly after he was appointed editor of Rapport, which the interviewer described as 'Afrikaans media's last roll of the dice' (Leonard 2013).

The question is: is the inclusion of contributions in and about colloquial Afrikaans in the established newspapers merely a case of serving 'side-dishes' and therefore not profitable - or does it actually have a different function? In the following section the focus is on the allocation of space to colloquial varieties, Kaaps in particular, in these established Afrikaans newspapers.

\section{KAAPS IN TRADITIONAL AFRIKAANS NEWSPAPERS}

This section on the use of Kaaps in the mainstream or traditional Afrikaans papers draws on the Kuper Report that was discussed extensively by the full editorial team of Rapport in 2012 (see section 9.1). In this report the performance and positioning of Die Burger, Beeld, Volksblad and Rapport were under scrutiny. The forms of Afrikaans used in these papers and the language preferences of their readers were among the other points of discussion. In short, the language picture painted in the report, was as follows:

All these newspapers were generally praised for their 'pure Afrikaans' which pointed to these publications as trustworthy news sources. Especially coloured readers deemed these papers to be of educational value, based on their 'high level' Afrikaans. In contrast, some readers indicated that the Afrikaans that is used, strips the stories of colour, making it sound like 'dictation'. Others admitted to having migrated to Son because the news is packaged in 'more pleasing' language, but they did not want to see the more 'vulgar' manifestations of it in mainstream papers. Instead, they wanted the other newspapers to engage the community in the manner of Son and Daily Voice.

In the past decades, Kaaps has indeed gained access to the mainstream Afrikaans newspapers, albeit on a much smaller scale than in Son. The creation of space for this variety in Die Burger, Beeld and Rapport has been achieved in two ways.

The first one is the sporadic publication of literary or linguistic contributions in which Kaaps, or aspects of it, are discussed. Titles like the following give a clear indication that Kaaps is central to these contributions: 'Kort vokale so eg Kaaps as kan kom' [Short vowels as Kaaps as they come] (Anonymous 2002a); 'Kaapsers maak lang vokale kort. Dit was beslis die laaste hanekloot' [Speakers of Kaaps shorten long vowels. That was definitely the last cock's testicle] (Anonymous 2002b); 'Small het Kaaps in Afrikaanse poësie gevestig' [Small established Kaaps in Afrikaans poetry] (Coetzee 2001); “Kaap-se-taal” allermins net 'n mistykie' [Cape language not a little mistake at all] (De Vries 2001); 'Kaaps, taal van my hart' [Kaaps, language of my heart] (De Vries 2006); 'Bal die vuis vir Kaaps' [Make a fist for Kaaps] (Le Cordeur 2010) and 'Kaaps is nie Capey nie' [Kaaps is not Capey] (Snyders 2002a). Also of relevance in this regard are the contributions of, among others, Llewellyn Prince, Kay Karriem, Alicestine October and Maygene de Wee in Die Burger's daily column Van alle Kante [From all sides].

A second point of entry for Kaaps in the mainstream print news media 
is through columns in which Kaaps as writing code is prominent. Examples of these columns are Peter Snyders' Kopstukke (in Die Burger) ${ }^{2}$, Anastasia de Vries Duskant Maandag (in TYD-Rapport) and Nathan Trantraal's Sypaadjies (in Rapport). Snyders as well as De Vries and Trantraal are competent in Kaaps and all of them have made their mark in the literary domain. For this reason, their columns are written in the form of stories or narratives reflecting different varieties of Kaaps.

In Kopstukke, Snyders focuses on the life and times of people on the Cape Flats. He created three characters, Ghoeroe, Doktor en Ralph, mouthpieces for his deep philosophical thoughts in Kaaps about issues like existentialism, identity, economic and political injustice and justice. Through his character 'Gediggies Dirk' he comments on Afrikaans literature and the literary establishment.

In her contributions to the magazine column Duskant Maandag Anastasia de Vries writes from the local space of Ravensmead about universal issues: being gay, parenthood, social and political injustice, and women's rights. A collection of these columns were later published in her anthology Baie melk en twie sykers (2010). Marius Crous (2010) would later comment on this work: 'All the way through she also uses [...] a Kaapse idiom which is particularly reflected in the dialogue, without obstructing the reading process.'

Trantraal also dedicates his column Sypaadjies to social commentary in Kaaps about the life of coloured people in townships on the Cape Flats. His description of his writing code on the website afrikaans.com, a platform that was created 'to celebrate and explore the diversity and beauty of Afrikaans', is also applicable to his column: 'My Afrikaans lyk soesie mense wat it praat. Die geskiedenis van Coloured mense is heeltemaal locked up innie Afrikaans wat hulle praat. Is Engels, Dutch, Malay, Indonesian Arabic, Khoe. Dis ' $n$ version van Afrikaans wat unedited is, sône gatekeepers en sône affectations' [My Afrikaans looks like the people who speak it. The history of coloured people is completely locked up in the Afrikaans they speak. It is English, Dutch, Malay, Indonesian Arabic, Khoe. It's a version of Afrikaans that is unedited, without gatekeepers and without affectations.]

These three writers display differences and similarities concerning the use of Kaaps as narrative and citing code. To explain this observation, extracts from a column of each will be discussed below (see examples e-g). The key applied to the discussion of the column 'Oom Sonnie se stukke', also applies here: the parts of the text where the narrator speaks (the narrative code), is in regular font; those in direct speech (citing code) is in bold, while characteristic Kaaps phenomena are underlined.

The narrator in Peter Snyders' 'People se outokrasie bieter as demokrasie' [People's autocracy better than democracy] uses mostly utterances peppered with typical Kaaps linguistic elements, as the extract (e) below makes clear (see the parts of texts in regular font). With the exception of one utterance 'Hy wou haar verkrag' [He wanted to rape her], this observation is also applicable to all the other utterances appearing in direct speech (see the parts in bold).

Example (f) below is an extract from Anastasia de Vries' column 'Die lewe is 'n speeltoneel' [Life is a drama].

2 Notably, Snyders had already published columns in Kaaps in 1998 in Beeld, northern sister newspaper of Die Burger, before his weekly column Kopstukke appeared in the Cape newspaper in the years 2000. 
As in this extract, the utterances of her Ravensmead characters, often contain typical Kaaps elements (see the parts in bold). In contrast, the parts where her narrator speaks, is sometimes written in informal Standard Afrikaans (like in the opening part of the extract (f)), and other times (as in the utterance 'Nie, sweer ant Myra, soe whallai kassiem, daai dae voor Paasfees het die mense in haar plek ' $n$ oop hand' [No, swears aunty Myra, true as Bob, those days before Easter, the people in her place have an open hand]), an informal standard variety with linguistic markers of Kaaps.

Extract (g) can be found in Nathan Trantraal's column 'My antie maak home movies en ôs kyk 'it oo en oo' [My aunty makes home movies and we watch them over and over]. This extract illustrates the typical linguistic presentation in Trantraal's texts: essentially narratives in the third person cast in Kaaps with characters who seldom speak for themselves.

(e)

EK begin al hoe meer die wêreld deur Ghoeroe se oë te sien. Ghoeroe sê: "God is dood. Demokrasie, die antichris, het sy plek ingeniem.'

Die ergste van hierdie demokrasie is dat hoeggeleerde djitse en magistrate klou aan hulle wette soes snot aan ' $\mathrm{n}$ handdoek, al lyk die wet hoe verkeerd te wies. En wat van die arme wetsgehoorsame mense? Hoe's demokrasie met hulle?

Nië, wat, hulle moet maar aanhou om te fast op "n leë maag. Hulle het in elke geval nie die geld om vir kwaai lawyers te betaal nie. Dis of course anneste met die ghêngs en organised kraaim. Die wetsgehoorsame mense se grootste vyand is daai djitse en lawyers wat soe volhou: Die wet is die wet.
Ghoeroe en Piering was een dag ' $\mathrm{n}$ plakkerskamp in met carriers vol klere wat hulle koelek het. Terwyl die hoofvrou en haar luitenant vir hulle 'n flagontjie maak, kom twie ouens en ' $n$ vrou met ' $n$ dronkie daar in. "Hy wou haar verkrag," sê een van die manne met sy arm onner die dronk ou se armpit.

Die hoofvrou verlaat toe saam met hulle na " $\mathrm{n}$ anner kamer. Toe die hoofvrou die sakie afgehandel het, kom sy trug na Ghoeroe en Piering en sê: "Ons los maar onse eie problempies op. Die lô sal in any case nie iens kom nie."

Nou daai is wat ek kôl people's outokrasie; iets bieter as demokrasie. As djy skullag is, is djy skullag en te hel met al jou smaart mondstukke. Demokrasie moet af en toe gebuig word.

(Snyders 2002b)

(f)

Dis die week voor Paasfees.

En sy weet: van môre af word die strate van Ravensmead 'n skouspelagtige opelugteater. As die eerste vishoring sy hees gebalk oor die Lane uitstuur en die perde kopspelend voor die groentekar aangetrippel kom ... word die lewe 'n speeltoneel!

(...)

En môre sal 'n stem oor die reuk van vars vis heen die vroue straat toe roep: "Snoek! Snoek! Twennie rên vi twie. Lekke vet, lekke vasse, vasse viste! Ky'ra-da, dié viste het tot nettoutjies nog lekketjies rondgeswem!"’

Nie, sweer ant Myra, soe whallai kassiem, daai dae voor Paasfees het 
die mense in haar plek 'n oop hand. Maar nou ja, as jy nie daar is nie, moet jy maar haar woord daarvoor vat.

Of vra vir Toeroerie, sy wat al die laaste dertig jaar of meer elke elke jaar dié tyd dieselle ou rympie sommer oor die draad (tussen hul huise) uitskree: "Myrieee! Djy moet wee vi my van daai mittedjale vi my ingelêde vis gie, gehoor? Die ou ding va my, askies my ou beste, het hom laas jaa skoons blinkbek ge-iet an jou vis!"

(De Vries 2010:49-50)

(g)

My antie is nou oppie screen, sy pretend om die kameraman weg te jaag, wan sy hou nie van aandag 'ie. My antie direct, edit, produce en is die lead actor in al haa home videos, maa elke film begin met haa wat 'n monologue gie oo hoe sy aandag haat. Sy gooi parties met haa kosgeld, soedat sy die video's kan maak.

My antie is soes Klaus Kinski, sy is mal en lief virrie kamera. Die res vannie video is net klomp mense wat iet, die heeltyd, maa gross. 'n Klomp ytgevriete mense wat gevang wod op camera, soes dai scene in Spirited Away waa Chihiro se parents in varke ve'anne van gimbageid.

Die second act is essentially alternate versions vannie macarenavideo. Niks much gebeu hie oek'ie, behalwe dat een van my antie se niggies die vrou ookant die pad try om te force om te dans op die macarena. Die antie ookant die pad ruk die niggie se hand los, met al die meanness wat sy kan muster. Jy kan sien my antie skinne baie by die vrou oorie niggie, my antie hettie gebother om die stukkie yt te edit 'ie. (Trantraal 2016b)
As presentations in newspapers of which a large number of readers are not proficient in Kaaps, these three columns collectively, if implicitly, draw attention to the linguistic and contextual aspects of Kaaps. All these columns reflect many of the linguistic markers described by Hendricks (2016) and, among others, also by Ernst Kotzé (1984). Typical Kaaps phenomena in (e), (f) and (g) comprise among others direct borrowing from English (carriers, muster); morphological embedding of English lexical items (flagontjie, gebother); common lexical items (dronkie for dronkaard [drunkard], mittedjale for (speserymengsel) spices, the exclamation ky'ra-da (Kyk daar![Look there!])); pronunciation phenomena such as /e/-elevation (bieter, nië, wies), /o/-elevation (hoeggeleerde), post-vocal /r/-omission (maa, skinne, vi) and /a:/shortening (an).

The linguistic differences manifesting in the columns of Snyders, De Vries and Trantraal are threefold:

The first difference pertains to the form of Kaaps that is reflected. Snyders uses an older form of Kaaps that was/is spoken on the wider Cape Flats and specifically the southern suburbs of Cape Town. Trantraal's column reflects the Kaaps of townships like Bishop Lavis and Mitchells Plain. The Kaaps in De Vries' contributions is that of the northern suburbs of Cape Town, in particular Ravensmead. Collectively these three columns shed light on the heterogeneous nature of Kaaps.

The second difference is idiolectic preference. Each of these columnists' use of Kaaps reflects her/his own selection from the many options within a heterogeneous variety such as Kaaps. 
Thirdly these columnists differ regarding the orthographic presentation of Kaaps. They reflect for example the following differences: the use of the umlaut to indicate the elevation of /e/ is only typical of Snyders: liëwe (Snyders 2001), nï̈ (Snyders 2002b), onsiëker (Snyders 2002b), tiën (Snyders 2002b). The pronunciation of almal [everybody] as [amol] is written differently: ammel (Trantraal 2016a), ammil (Snyders 2002b). The use of the apostrophe to indicate the omission of a sound, is characteristic of Trantraal's phonetically written text: 'Moenie act soes jou ma en pa, wie nie wiet Facebook issie die hys 'ie, jy kannie net maak en doen soes jy wil 'ie. En ek sê it'ie genoegie, maa ek dinkie alle wit mense is racist ' $i e$ ' [Do not behave like your mother and father who do not know that Facebook isn't home, you can't make and break as you see fit. And I don't say it enough but I do not think all white people are racist] (Trantraal 2016a).

These differences result from the fact that written Kaaps, especially the tradition to write phonetically, has yet to be regularised for greater uniformity. Writers who use Kaaps are still (thankfully?) obliged to use their own discretion and creativity.

\section{CONGLUSION}

The use of Kaaps, quite freely as indicated in an Afrikaans tabloid like Son and the space allocated to this variety in the Afrikaans mainstream newspapers, is an implicit acknowledgement of the value of this Afrikaans language form as a journalistic medium.
The differences in writing in Kaaps may necessitate the development of a normative writing system for Kaaps which could be to the benefit of journalists, as well as the creators of literary texts. A step in this direction should be taken with caution as it could lead to prescription and the restriction of options. In a contribution to Die Burger's column Taalskatkis, Ponelis (2004) cautions that we should be sober and practical in matters regarding how Afrikaans should be written: 'Let us be grateful that Afrikaans has an orthography that correlates with its pronunciation. At the same time, we should approach the principle that we write the way we speak in a sober and practical manner.'

Further studies about columnists' approaches to the orthography of Kaaps can shed light on how 'sober' and 'practical' their writing principles are. However, the differences regarding the orthographic reproduction of Kaaps is not the main issue. In my opinion the importance of their work lies in the concrete proof they offer that Kaaps, just like the standard variety of Afrikaans, can be convincingly used as a vehicle for deep philosophical thought and sociopolitical commentary. Above all, they are written confirmation that Kaaps can function as a vital, 'valid communication code' (Hendricks 2012b:111) in any and all Afrikaans newspapers.

\section{REFERENCES}

Anonymous. 2002a. 'Kort vokale so eg Kaaps as kan kom.' Die Burger Landelik, 23 April. http://152.111.1.87/argief/ berigte/dieburger/2002/04/23/9/19.html. Accessed: 9/6/2011. . 2002b. 'Kaapsers maak lang vokale kort. Dit was beslis die laaste hanekloot.' Die Burger Landelik, 21 
Mei. http://152.111.1.87/argief/berigte/ dieburger/2002/05/21/11/1.html. Accessed: 9/6/2011.

Audit Bureau of Circulations of South Africa. ABC Q4 2015. http://www.abc.org.za

Blignaut, Joline. 2014. 'n Ondersoek na die taalgebruik in Son as verteenwoordigend van Kaapse Afrikaans. Unpublished M.A. thesis: Stellenbosch University.

Coetzee, Ampie. 2001. 'Small het Kaaps in Afrikaanse poësie gevestig.' Die Burger, 5 November. http://152.111.1.87/argief/ berigte/dieburger/2001/11/05/11/1.html. Accessed: 5/10/2011.

Crous, Marius. 2010. Die twee gesigte van Ravensmead. In: Literator 31 (2). Augustus, 2010.

De Vries, Anastasia. 2001. “"Kaap-se-taal” allermins net 'n mistykie'. Die Burger, 26 Junie. http://152.111.1.87/argief/ berigte/dieburger/2001/06/26/9/10.html. Accessed: 2/6/2016. . 2006. 'Kaaps, taal van my hart'. Perspektief, Rapport, 23 Julie. http://152.111.1.87/argief/berigte/ rapport/2006/07/23/RP/1/01.html. Accessed: 2/6/2016. . 2010. Baie melk en twie sykers. Protea: Protea Boekhuis. 2015. Wie mag Kaaps in wie se Kaaps? 'n Ondersoek na die gebruik van Kaaps in Marlene van Niekerk se Kaar. Stilet XXVII(2): 1-16.

Hendricks, Frank. 2010. Op die taalspore van S.V. Petersen: 'n blik op sy verrekening van taaldiversiteit. Tydskrif vir Nederlands en Afrikaans (T.NEA): 17(2): 21-37. . 2012a. Die potensiële nut van 'n gelykevlak-perspektief op die variëteite van Afrikaans. In: Prah (red.). 2012. CASAS Book Series no. 88: 44-63. . 2012b. Om die miskende te laat ken - ' blik op Adam Small se literêre verrekening van Kaaps. Tydskrif vir Letterkunde 49(1): 95-114. . 2014. Die verrekening van taalvariasie in die prosawerk van Elias P. Nel. LitNet Akademies 11(2). http://www.litnet.co.za/ Article/die-verrekening-van-taalvariasiein-die-prosawerk-van-elias-p-nel. Accessed: 2/6/2016.
Jason, Eldridge. 2012a. 'Pokken Booze hoor sy dae is getel'. Oom Sonnie se stukke, Son, 13/11/2012. http:// m24arg02.naspers.com/argief/berigte/ dieburger/2012/11/13/KS/10/ss\%20 sonnie21-195.html .2012b. "Pokken dink dis tickets methom". Oom Sonnie se stukke, Son, 22/11/2012. http://152.111.1.87/argief/ berigte/dieburger/2012/11/22/KS/8/ oomsonnie2 1 nov-251.html . 2015. “'n Gangster se dreigement laat Klaas erg worry". Oom Sonnie se stukke, Son, 20/7/2015.

http://www.son.co.za/Sonmobiclub/ Oomsonnie/N-GANGSTER-SEDREIGEMENT-LAAT-KLAAS-ERGWORRY-20150720

Karriem, Kay. 2013. Kuier-ing is changing the media landscape. In: The Media Online. 25 Junie 2013. http:// themediaonline.co.za/2013/06/is-kuiering-changing-the-media-landscape

Kotzé, Ernst F. 1984. Afrikaans in die Maleierbuurt: 'n Diachroniese Perspektief. Tydskrif vir Geesteswetenskappe 24(1): 41-73.

Kuper Research, Media24 Afrikaans Newspapers Market Analysis: A qualitative probe into relevant reader groups. Februarie 2012.

Le Cordeur, Michael. 2010. Bal die vuis vir Kaaps. Die Burger, 17 Maart, bl. 11. http://152.111.1.87/argief/ berigte/dieburger/2010/03/17/SK/11/ forum 17mrt.html Accessed 2/6/2016.

Leonard, C. 2013. Is Waldimar Pelser Afrikaans media's last roll of the dice? Mail and Gaurdian. 19 April.

Ponelis, Fritz. 2004. Ons skryf in Afrikaans soos ons praat. Die Burger, 24 Februarie. http://152.111.1.87/argief/berigte/ dieburger/2004/02/24/DB/13LDNk/05. html

Prah, Kwesi Kwaa (red.). 2012. Veelkantiger Afrikaans: Streeksvariëteite in die standaardvorming. CASAS Book Series no. 88 .

Smith, Salmon. 2010. 'Klein Lucien word deur 'n mal man gejaag in die nanag'. Oom Sonnie se stukke, Son, 12/7/2010. 
http://152.111.1.87/argief/berigte/ dieburger/2010/07/12/KS/11/ss\%20 sonnie17junie-102.html . 2013. 'Mistas wil 'n voorbeeld van Jeppo maak'. Oom Sonnie se stukke, Son, 21/2/2013. http://152.111.1.87/ argief/berigte/dieburger/2013/02/21/ KS/9/OomSonnie-21 Feb2013.html

Snyders, Peter. 2001. 'Kuns se groot geheim is: "doen soes die voëls en die lilies". Kopstukke, Die Burger, 4 Oktober. http://152.111.1.87/argief/berigte/ dieburger/2001/10/04/4/19.html . 2002a. 'Kaaps is nie Capey nie'. Taalskatkis, Die Burger, 26 Maart. http://152.111.1.87/argief/berigte/ dieburger/2002/03/26/9/4.html. . 2002b. 'People se outokrasie bieter as demokrasie'. Kopstukke, Die Burger, 12 September. http://152.111.1.87/argief/ berigte/dieburger/2002/09/12/4/32.html . 2002c. 'Byname pla (gewoenlik) nie'. Kopstukke, Die Burger, 21 November. http://152.111.1.87/argief/berigte/ dieburger/2002/11/21/DB/14LDNk/05. html

Trantraal, Nathan. 2016a. 'Hou 'n braai en praat jou racist hartjie daar uit'. Sypaadjies, Rapport Weekliks, 24/1/2016)http://152.111.1.87/argief/
berigte/rapport/2016/01/25/RW/24jan_ nathan_33_0_497774185.html . 2016b. 'My antie maak home movies en ôs kyk 'it oo en oo'. Sypaadjies, Rapport Weekliks, 1/5/2016) http://152.111.1.87/ argief/berigte/rapport/2016/05/03/ RW/1mei_nathan_34_0_223078993.html Van der Rheede, Christo. 2012. Die rol van Afrikaanse poniekoerant die Son in die belyning van geografiese variëteite van Afrikaans met die hoofstroom. In: Prah (red.). 2012. CASA Book Series no. 88: 112-124.

Williams, Tracy-Lynn. 2016. 'Ouma Doris is in trane oor meer as dobbelgeldjies'. Oom Sonnie se stukke, Son, 30/5/2016. http:/www.son.co.za/Sonmobiclub/

Oomsonnie/ouma-doris-is-in-trane-oormeer-as-dobbelgeldjies-20160530

Anastasia de Vries delivered this contribution in her previous capacity as assistant- and literary editor for the newspaper Rapport. Sy is currently a lecturer in Afrikaans and Nederlands at the University of the Western Cape. 